\title{
EL BOSQUE COMO TEMPLO DE LA FILOSOFÍA: HENRY DAVID THOREAU Y LOS ENEMIGOS DE LA CIUDAD
}

\section{THE FOREST AS THE TEMPLE OF PHILOSOPHY: HENRY DAVID THOREAU AND THE ENEMIES OF THE CITY}

\author{
Santiago Beruete Valencia* \\ UNED
}

Resumen: Este artículo intenta analizar la impronta que H. D. Thoreau, figura icónica por excelencia del antiurbanismo, ha dejado en F. L. Olmsted, padre del paisajismo norteamericano y creador del Central Park, en el arquitecto de Estados Unidos probablemente más influyente de todos los tiempos, F. L. Wright, y en los miembros de uno de los últimos y más activos movimientos artísticos, el Land Art, muy especialmente en R. Long y H. Fulton. A partir de los textos originales, ilustraremos cómo su radical ejemplo ha cundido en algunos de los más influyentes representantes de la cultura anglosajona, quienes, tras sentir la irrefrenable llamada de la naturaleza salvaje, optaron por dar la espalda a la ciudad en aras de una vida más auténtica. Hemos acuñado la expresión síndrome de Thoreau para designar ese arrebato que llevó a algunos de los más distinguidos pensadores y creadores a argumentar que las urbes se habían tornado indeseables.

Palabras clave: Antiurbanismo, Jardinería paisajista, Arquitectura orgánica, Pintoresquismo pragmático, Land art.

Aвsтract: This article aims to analyze the imprint that H. D. Thoreau, iconic figure par excellence of anti-urbanism, made on F. L. Olmsted, the father of North American landscape gardening and creator of New York's Central Park, on F. L. Wright, perhaps

* Dirección postal: C./ Ignasi Wallis, 33, 07800 Ibiza (Illes Balears) E-mail: beruete1@hotmail.com. Este artículo se realizó en el marco del proyecto de investigación de la tesis doctoral titulada «Los jardines de la utopía: ética, estética y política» leída el pasado mes de junio y dirigida por D. Ramón del Castillo dentro del Programa de Doctorado 1003001 - «Lectura e Historia» del Departamento de Filosofía (Facultad de Filosofía de la UNED). 
the most influential United States architect of all times, and on the members of one of the last and most active artistic movements, Land Art, especially on R. Long and H. Fulton. Using the original texts, we will illustrate how their radical example spread among some of the most influential figures of Anglo-Saxon culture, who, after feeling the call of wild nature, decided to turn their backs on the city for the sake of a more authentic life. We have coined the expression Thoreau's syndrome to designate the outburst that led some of the most distinguished thinkers and artists to argue that cities had become undesirable.

KeY words: Anti-urbanism, Landscape Gardening, Organic Architecture, Pragmatic Picturesque, Land Art.

\section{Una figura icónica del antiurbanismo: Presentación}

Algunos de los intelectuales norteamericanos más influyentes y representativos manifiestan desconfianza, cuando no antipatía o rechazo, hacia las ciudades, a las que denostan porque «son pestilentes para la moral, la salud y las libertades del hombre» (T. Jefferson), «vuelven a los hombres superficiales» (R. W. Emerson), acogen «muchedumbres vulgares» (H. Melville) o representan «un Babel de falsos principios y ambiciones ciegas» (J Santayana). Bien sea porque «no hay nada como una muchedumbre para que uno se sienta solo» (H. James), bien sea porque «la Gran Sociedad creada por el vapor y la electricidad puede ser una sociedad, pero no es una comunidad» (J. Dewey), o sencillamente porque «la existencia misma de una gran ciudad crea problemas de higiene, de vida familiar y de control social, que no existían cuando el hombre vivía en el campo" (A. Park), las aglomeraciones urbanas revisten un aire sórdido e inicuo para muchos escritores, que, desde posiciones tanto ilustradas y empíricas como trascendentalistas o socialistas utópicas, observan sus calles bajo una luz tenebrosa.

En su asombroso y esclarecedor ensayo El intelectual contra la ciudad, Morton y Lucía White han demostrado cómo el eco del antiurbanismo se oye en un autor tras otro del panteón literario y filosófico norteamericano a lo largo de casi dos siglos, componiendo un único canto, una música de fondo. Oigamos sus argumentos:

Pues en tanto que nuestra sociedad se hizo cada vez más urbana durante el siglo XIX, la tendencia a denigrar la ciudad apenas disminuyó; más bien se acrecentó su intensidad. Uno de los elementos más típicos de nuestra vida nacional, la ciudad en expansión, se convirtió en la bête noire de nuestros 
intelectuales más destacados, en vez de constituirse en su favorita. Resultaría sumamente difícil entresacar de sus escritos una extensa antología de poesía o filosofía social celebrando la vida urbana norteamericana. Dejando de lado lo que la gente común pueda haber sentido por Boston, Chicago o Nueva York; dejando de lado las vociferaciones de las cámaras de comercio y de los oradores de fiestas patrias, los principales escritores norteamericanos nunca se levantaron al unísono para saludar la metrópoli con entusiasmo ${ }^{1}$.

Quizá haya que buscar la explicación a esa actitud crítica, cuando no beligerante, hacia la urbe en el hecho de que los padres fundadores de la nación eran granjeros imbuidos de una ideología que ensalzaba la pureza de la vida rural en el Nuevo Mundo por oposición a la corrupción moral de las ciudades, que habían dejado atrás en el Viejo Continente. La utopía pastoral, muy presente en algunos de los más sobresalientes intelectuales, hunde sus raíces en lo que el crítico Lewis Mumford se complace en llamar «el romanticismo del pionero» («romanticism of pioneen) y que pocos escritores encarnan mejor que Henry David Thoreau (1817-1862).

Veremos en el curso del presente artículo cómo el autor de Walden, figura icónica par excellence del antiurbanismo, ha dejado su poderosa impronta en Frederick Law Olmsted (1822-1903), padre del paisajismo norteamericano y creador del Central Park, en el arquitecto de Estados Unidos probablemente más influyente de todos los tiempos, Frank Lloyd Wright (1867-1959), y en los representantes de uno de los últimos y más activos movimientos artísticos, el Land Art, muy especialmente en Richard Long (1945) y Hamish Fulton (1946). Intentaremos mostrar cómo periódicamente su radical ejemplo cunde entre los representantes de la cultura anglosajona, que sienten la irrefrenable llamada de la naturaleza salvaje y optan por dar la espalda a la ciudad en aras de una vida más auténtica. Utilizando una expresión quizá excesiva, hemos dado en llamar el sindrome de Thoreau a la convicción que se apodera de algunos de los más distinguidos y eminentes pensadores y literatos de que las urbes son indeseables. De ahí también que, esgrimiendo argumentos de muy diversa índole, decidan romper con la civilización para buscarse a sí mismos y la felicidad lejos de la selva urbana ${ }^{2}$.

1 White, M. y L. (1967). El intelectual contra la ciudad. De Thomas Jefferson a Frank Lloyd Wright, trad. de E. L. Revol, Buenos Aires: Ediciones Infinito, Biblioteca de planeamiento y vivienda, p. 12.

2 Hay algo paradójico, y no por ello menos revelador, en utilizar este oxímoron y otros similares como jungla de asfalto para referirse a las ciudades modernas. Esa asociación de términos, 
No pretendemos diseccionar todas las razones de ese rechazo a la ciudad, sino simplemente subrayar, huyendo tanto del panegírico como del retrato iconoclasta, que la vida y la obra de H. D. Thoreau marcan un hito en la poderosa tradición antimetropolitana norteamericana y han ejercido un magisterio decisivo sobre otros creadores. Como Morton y Lucía White se han preocupado en señalar, las críticas a la ciudad no han sido sólo dirigidas por autores que cuestionaban o despreciaban los valores de la civilización, véase T. Jefferson, $R$. W. Emerson, H. Melville o N. Hawthorne, sino también por urbanitas empedernidos y consagrados a la vida civilizada, tales como H. Adams, H. James, R. Park o J. Dewey. La tesis central de su ensayo se halla capturada en la siguiente frase: «En síntesis, la ciudad norteamericana se ha encontrado atrapada entre los fuegos cruzados de dos poderosos antagonistas: los primitivos y los refinados» ${ }^{3}$.

El más primitivo entre los primitivos, el menos académico de los intelectuales antimetropolitanos y el más anticonvencional de los clásicos es, sin género de duda, H. D. Thoreau, quien por la poética rudeza y el apasionamiento con que expresa su amor por la naturaleza salvaje, su valentía moral, su capacidad para pensar creativamente y el magnetismo que irradia su imagen y sus escritos, se ha ganado el respeto y la admiración de las generaciones futuras y se ha convertido en el espíritu guía de muchos destacados pensadores y artistas. Su carisma literario y filosófico no ha cesado de crecer desde que, a la temprana edad de 44 años, muriese de tuberculosis, dejando sin publicar la mayor parte de su obra.

Desde la perspectiva de un lector moderno, su figura se engrandece por muy diversos motivos. En primer lugar, su escritura, clásica en la forma pero romántica en el espíritu, toma como fuente de inspiración su propia vida, lo que conecta con el actual interés por el género de ficción biográfica, tan en boga en nuestros días. En segundo lugar, porque, como veremos, fue un pionero en la defensa de muchas causas que siguen plenamente vigentes: la protección del medio ambiente, la lucha por los derechos civiles, el antimilitarismo, la reivindicación del ocio creativo, adelantándose en esto varias décadas a El derecho a la pereza (1883) de Paul Lafargue. Y en tercer lugar, pero no menos importante, porque su pensamiento exhala alegría de vivir, trasmite confianza en las posibilidades del ser humano y promueve una estoica felicidad. Resulta asimismo fácil entroncar

aparentemente contradictorios, expresa una verdad tan profunda como elemental. La urbe, nacida del impulso humano de ordenar el espacio, se asemeja a la naturaleza salvaje cuando aquélla cede a la tentación del caos y retorna a sus orígenes. Parafraseando el verso de Horacio, la naturaleza vuelve en el mismo anhelo urbanizador con el que se le despacha.

3 Op. cit., p. 219. 
su filosofía vital con algunas de las últimas tendencias sociales como la afición al senderismo, el movimiento de las slowcities, la teoría del decrecimiento económico, el neohippismo y otras formas alternativas de insumisión y resistencia política. Todo ello lo convierte por derecho propio y, sin importar el tiempo transcurrido, en nuestro contemporáneo. Pero pese a su indiscutible modernidad, su figura tiene algo del humor irreverente, de la sagacidad provocadora y de la inclemente rectitud de un Sócrates, así como de la lúcida impertinencia y de la provocadora perspicacia de un Diógenes, y su mismo desapego por los bienes materiales, las convenciones sociales y las obligaciones laborales. Pertenece, en suma, a la rara especie de los pensadores que intentaron estar a la altura de sus ideales.

\section{Filosofía de la naturaleza y naturaleza de la filosofía en H. D. Thoreau, el robinsón de los bosques}

A medida que, parafraseando a Harry Levin ${ }^{4}$, Estados Unidos iba dejando de ser un jardín y perdiendo la inocencia al urbanizarse, la nostalgia de la naturaleza prístina y salvaje se iba haciendo cada vez más intensa. Nadie encarna mejor en su vida y en su obra el retorno a la pureza de los orígenes que $\mathrm{H}$. D. Thoreau. Su reacción militante contra la ciudad, que le oprime física, moral y psicológicamente, su voluntad de religarse con la tierra y hacer del bosque un templo de la filosofía, lo convierten no sólo en un exponente paradigmático del antiurbanismo sino también en un filósofo de la naturaleza o, como a él le gustaba definirse, un filósofo natural. Su concepción de ésta como una escuela de virtud moral y política ha calado muy hondo y ha contribuido a forjar el gusto de los creadores destinados a diseñar los jardines y los parques de Norteamérica. Su contribución a la estética del paisaje es comparable a la que tuvieron los teóricos del movimiento pintoresco en Inglaterra (Uvedale Price y William Gilpin). Ésta es una de las hipótesis heurísticas que sirven de hilo conductor a este trabajo.

En muchos de sus textos contrapone el jardín al bosque para ilustrar el creciente conflicto entre el hombre y la ciudad moderna. La diferencia que existe entre la naturaleza virgen, indómita y agreste, y la naturaleza artificial, domesticada y ordenada por la mano del hombre es del mismo orden que la que hay entre la libertad y la sumisión, entre la rebeldía y el conformismo, entre pensar y actuar por uno mismo y obedecer sin cuestionarse los prejuicios heredados. Con la poética rudeza que caracteriza su estilo escribe en Walking (1862):

\footnotetext{
${ }^{4}$ Op. cit., p. 44.
} 
Para mí la esperanza y el futuro no están en los jardines ni en los campos cultivados, en los pueblos ni en las ciudades, sino en los pantanos inaccesibles y movedizos. [...] Sí, aunque me consideréis perverso, si me propusieran vivir en el vecindario de los jardines más bellos que el arte humano haya concebido o en un «Pantano Deprimente», sin duda elegiría este último. ¡Qué vanos han sido para mí todos vuestros esfuerzos, ciudadanos! ${ }^{5}$

Con esa boutade, con esa provocadora exageración, no exenta de romanticismo, H. D. Thoreau pretende hacer bandera de su individualismo y reafirmarse en su credo filosófico, cuyo valor más sagrado es la independencia. Quien no quiera que sus alados pensamientos se conviertan en aves de corral, como sugiere elocuentemente pocas líneas después en el mismo texto, ni que sus pies echen raíces en el suelo, debe atreverse a tomar lecciones de bosque, a salirse de los caminos trillados y a perderse por senderos sin trazar a la búsqueda de sí mismo, pues como él mismo señala: "¿qué sería de nosotros si caminásemos solo por un jardín o una alameda?» ${ }^{6}$.

Esta cita también es un buen ejemplo de cómo sus bucólicos y, sólo en apariencia, ingenuos comentarios admiten una lectura política de implicaciones perturbadoras. Sus divagaciones encierran a menudo una carga de profundidad. Al cantar las alabanzas de la vida salvaje, pone de manifiesto la función moralizante, educativa y salutífera de los bosques. Vale la pena detenerse en este punto para subrayar que H. D. Thoreau considera que la naturaleza tiene un efecto benéfico sobre el espíritu, posibilita la renovación interior y hace más tolerable la existencia. Ese exacerbado naturalismo se refleja en frases como éstas: «La vida coincide con lo agreste. Lo más vivo es lo más salvaje. La presencia de la naturaleza no sometida al hombre lo renueva»?

Tanto en el tono como en el contenido de sus palabras recuerda a su admirado R. W. Emerson ${ }^{8}$, quien, en su famoso ensayo Nature (1836), escribió:

5 Thoreau, H. D. (1999). Pasear, trad. de S. Komet, Palma de Mallorca: José de Olañeta Editor, Los pequeños libros de la sabiduría, pp. 23-25.

${ }^{6}$ Op. cit., p. 11.

7 Op. cit., p. 22.

8 En el otońo de 1837 R. W. Emerson conoció a H. D. Thoreau, quien, a la sazón, contaba catorce ańos menos y acababa de graduarse en la universidad de Harvard. En su biblioteca había leído con apasionamiento el ensayo sobre la naturaleza del que empezaba a considerar un genuino maestro, y cuya compañía pronto frecuentaría. A pesar de las diferencias de edad, carácter, posición social y reconocimiento público, con el paso del tiempo se fue trenzando entre ambos hombres una amistad tan sincera como estrecha, que, pese a los comprensibles paréntesis, altibajos y 
En los bosques retornamos a la razón y a la fe. Allí siento que nada puede ocurrirnos, ninguna desgracia o calamidad -si me dejan los ojos- que la naturaleza no pueda reparar. De pie sobre la desnuda tierra, con la cabeza bañada por la felicidad del aire y alzada hacia el espacio infinito, todo egotismo interesado se desvanece?

Sin caer en la poesía barata de la new age y de la psicología de autoayuda, pocas dudas caben que caminar por los bosques y entrar en contacto con la tierra reportan beneficios físicos y mentales. Repone nuestra energía vital, serena nuestro ánimo y nos predispone al encuentro con nosotros mismos. Puede que ese mensaje nos resulte tópico, pero eso no le resta valor, por más que no resuene en nuestros oídos, desengańados ciudadanos del siglo XXI, con la misma exaltada frescura y romántica intensidad que cuando H. D. Thoreau escribió:

Fui a los bosques porque quería vivir deliberadamente, enfrentarme solo a los hechos esenciales de mi vida y ver si podía aprender lo que la vida tenía que enseñar, y para no descubrir, cuando tuviera que morir, que no había vivido. No quería vivir lo que no fuera la vida, pues vivir es caro, ni quería practicar la resignación a menos que fuera completamente necesario. Quería vivir con profundidad y absorber toda la médula de la vida, vivir de manera tan severa y espartana como para eliminar cuanto no fuera la vida ${ }^{10}$.

desengaños mutuos, duraría toda la vida. Fue, ésta, una relación decisiva para ambos. Cada uno a su manera ejerció un poderoso influjo sobre su vecino y compañero de fatigas filosóficas. R. W. Emerson valoró la estimulante conversación y la devota compañía de su joven amigo, del que, según dejo escrito en diarios y cartas privadas, admiraba su integridad, sencillez y actitud inconformista; mientras que H. D. Thoreau encontró en el pensador trascendentalista a un padre espiritual, un interlocutor válido, al que hacer partícipe de sus inquietudes, así como a un protector cuando lo necesitó. R. W. Emerson no sólo le consiguió un trabajo como tutor del hijo mayor de su hermano, juez en Nueva York, sino que le cedió la parcela de Walden Pond, donde levantó su mítica cabaña. Y, según es creencia compartida por muchos historiadores, le animó a escribir su célebre diario, que, al final de sus días, sumaba más de dos mil páginas. H. D. Thoreau, por su parte, desempeñó en ocasiones funciones de secretario, mayordomo y hombre de confianza de su amigo. Y en las largas temporadas en que éste se ausentaba de su residencia en Concord a causa de sus viajes y giras de conferencias, cuidó como si fuera su propia familia de su esposa e hijas, al tiempo que echaba una mano en las reparaciones domésticas.

9 Emerson, R. W. (2009). Obra ensayística, traducción y prólogo de C. Jiménez Arribas, Tenerife-Valencia: Artemisa Ediciones /Clásica n. ${ }^{\circ} 16$.

10 Thoreau, H. D. (2005). Walden, ed. de J. Alcoriza y A. Lastra, Madrid: Cátedra, Letras Universales n. ${ }^{\circ} 375$, p. 138. 
El hecho de denigrar la ciudad no presupone, ni mucho menos, en el caso de Thoreau una reivindicación de la vida rural, una defensa de las pequeñas comunidades agrícolas, una vocación aldeana o una apuesta por el provincianismo. Nada más lejos de su mentalidad. A diferencia de otros autores, su aversión hacia la ciudad no nace de planteamientos moralistas o puristas sino de la ansia de libertad, del afán de despojarse de todo lo innecesario y simplificar la existencia a lo esencial para, como él mismo declara, ver si podía aprender lo que la vida tenía que enseńarle. Su desprendimiento de los bienes materiales, su desapego mundano y su rechazo del mercantilismo imperante forman parte esencial también de su ideario. Parece hacer suya la vieja máxima de los estoicos y los cínicos, según la cual no es más rico quien más tiene sino quien menos necesita. En su obra Walden, or the Life in the Woods (1854), considerada como una auténtica biblia del antiurbanismo y donde despliega lo mejor de su agreste talento, escribe:

Aunque la pobreza restrinja vuestra esfera de acción y no podáis comprar libros ni periódicos, por ejemplo, quedareis limitados a las experiencias más significativas y vitales; os veréis obligados a tratar con la materia prima que proporciona más azúcar y vigor. Cuando la vida está en los huesos es más dulce ${ }^{11}$.

Esa ardiente defensa de la libertad interior como valor supremo lo aproxima, sin duda, a los representantes de las escuelas socráticas menores, que preconizaron la ataraxia o imperturbabilidad. Su ética del desapego aspira a alcanzar esa sabiduría ascética y práctica que nace de conocerse a uno mismo y saber lo que nos hace felices. Escuchemos de nuevo a H. D. Thoreau:

Ser un filósofo no es sólo tener pensamientos sutiles, ni siquiera fundar una escuela, sino aunar la sabiduría y vivir de acuerdo con los dictados de una vida de sencillez, independencia, magnanimidad y confianza. Es resolver ciertos problemas de la vida, no sólo en la teoría sino también en la práctica ${ }^{12}$.

No debemos dejarnos engañar por el contagioso entusiasmo y el falso candor de sus palabras. Su aparente sencillez encubre una profundidad ajena a la pomposidad académica y a la charlatanería intelectual. Su estilo llano, directo, vivaz y, sin embargo, sensible a la poesía de la naturaleza, se aleja del lenguaje esotérico de los pensadores profesionales, de las teorías de altos vuelos y de las

11 Op. cit., Economía, p. 67.

12 Op. cit., Economía, p. 71. 
honduras metafísicas para centrarse en lo elemental y lo cotidiano. Una sola de sus anécdotas o comentarios encierra más sabiduría que muchos tratados. No creo equivocarme si afirmo que el tema de sus ensayos es el cultivo de uno mismo. No nos hallamos ante la creación de un personaje, como ocurre en la literatura del yo, sino ante una filosofía en primera persona, a un genuino ejercicio de reflexión creativa y a un autorretrato andante. Sus textos escapan a los géneros, pues aúnan el ensayo, la narrativa, la literatura de viajes, la poesía, el reportaje, las memorias, el cuaderno de campo y el diario. Esa habilidad para combinar meditaciones filosóficas con simples anécdotas, apuntes de naturalista, comentarios históricos o divagaciones poéticas, sazonando el conjunto con toques de ironía y sentencias ocurrentes, dota a su estilo de una frescura sin igual. El resultado de esa abigarrada suma de ingredientes podría haber sido una escritura farragosa, desgarbada e impenetrable, en vez de la grácil, sutil y liviana prosa con que nos invita a seguirle por los caminos del bosque y de la mente.

Es dueño de una voz propia, poderosa e inconfundible, que lo convierten en un escritor único en su especie, una mezcla de viajero esteta y naturalista ácrata, de robinsón de los bosques y ermitaño ilustrado, de filósofo silvestre y poeta montaraz. Aunque su estilo es más lírico que épico, hay algo sin duda de gesta en su empeńo por seguir los dictados del corazón sin concesiones ni cortapisas. Sus páginas respiran una autenticidad inusitada y un sugerente aliento de aventura. Importa menos lo que dice que cómo lo dice. A fin de cuentas, su roussoniano retorno a la naturaleza, su romántica celebración de las bondades y bellezas de los bosques, por no mencionar su emersoniano idealismo filosófico, tienen poco de original, pero no así su manera de expresar el gozo sensual e intelectual de caminar por el campo, de respirar al aire libre y de contemplar el espectáculo de la vida salvaje. Después de todo, como observó G. Steiner, «la originalidad es la antítesis de la novedad $»^{13}$. Leyendo a H. D. Thoreau, a veces se tiene la impresión de que escribe como vive, con esa falta de artificio que es la más sofisticada forma de artificio.

Tal vez porque nunca busca nuestra complicidad, ni se muestra complaciente, ni si se esfuerza en convencernos, o tal vez por eso mismo, consigue persuadirnos. El placer de la lectura es, sin género de duda, el principal argumento a favor de sus ideas. La euforia que destilan sus palabras tiene el poder de seducirnos, de ganarnos para su causa, sea ésta cual sea. En un, no por breve menos denso, ensayo titulado engañosamente La vida sin principios, publicado normalmente junto a La desobediencia civil,

13 Steiner, G. (1991). Presencias reales, trad. de J. G. López Guix, Barcelona: Destino, p. 42. 
resume su filosofía vital con jovial rotundidad. Allí, frente a la laboriosidad alentada por la ética protestante del trabajo aboga por un empleo creativo del tiempo y una holganza activa y mentalmente productiva. Oigamos como argumenta de un modo muy suyo: «Yo creo que no hay nada, ni siquiera el crimen, más opuesto a la poesía, a la filosofía, a la vida misma, que este incesante trabajar» ${ }^{14}$. Y por si quedara alguna duda sobre su postura, pocas líneas más adelante declara: «Si tuviera que vender mis mañanas y mis tardes a la sociedad, como hace la mayoría, estoy seguro que no me quedaría nada por lo que vivir ${ }^{15}$. Frente al culto a la riqueza y al mercantilismo defiende un ascetismo liberador, cuyo núcleo más significativo queda explícito en la frase que ahora reproducimos: «Los caminos por los que se consigue dinero casi, sin excepción, nos empequeñecen ${ }^{16}$. Frente al conformismo y la abulia social alienta un rechazo a lo establecido y un sano espíritu contestatario, que queda patente en afirmaciones como la siguiente: «Las formas con las que la mayoría se gana la vida, es decir, viven, son simples tapaderas y un evitar el auténtico quehacer de la vida, y sucede así porque, en primer lugar, no saben; pero en parte también porque no quieren hacer nada por aprender algo mejor ${ }^{17}$.

Las dos anécdotas más conocidas de la vida de H. D. Thoreau, que cimentaron precisamente su fama de pensador asilvestrado y contestatario irreductible, son: su exilio voluntario de la civilización en una cabaña en medio del bosque y, mientras gozaba de ese solitario retiro, su detención e ingreso en prisión debido a su reiterada negativa a pagar los impuestos, como un acto de denuncia y protesta ante un estado que consideraba injusto por permitir la esclavitud y la guerra contra México. Ambos hechos retratan a un personaje tan rebelde como resuelto a hacer su voluntad. Parece haber interiorizado el consejo de su amigo y admirado R. W. Emerson, quien en su ensayo La confianza en uno mismo escribió: «Todo el que quiera ser un hombre, habrá de ser un inconformista» ${ }^{18}$.

La fecha del 4 de julio de 1845 marca un hito en la biografía de H. D. Thoreau. Con apenas veintiocho años, decide romper con las ataduras sociales

${ }_{14}$ Thoreau, H. D. (1987). 'Una vida sin principios' en La desobediencia civil y otros escritos, trad. de M. E. Díaz, Madrid: Tecnos, p. 5.

15 Op. cit, p. 6

16 Op. cit., p. 7.

17 Op. cit., p. 11.

18 Emerson, R. W. (2009). Obra ensayistica, traducción y prólogo de C. Jiménez Arribas, Tenerife-Valencia: Artemisa Ediciones /Clásica n. ${ }^{\circ}$ 16, p. 179. 
e irse a vivir solo al bosque. Se instalará en una cabaña ${ }^{19}$ que construyó con sus propias manos en Walden Pond, una parcela propiedad de su mentor y maestro R. W. Emerson (1803-1882). Ya que estamos hablando de cabañas, desviémonos un momento de nuestro propósito para hablar de otros relevantes intelectuales y artistas que, como H. D. Thoreau, sintieron la necesidad de apartarse de la civilización y buscar el aislamiento y la soledad en entornos inspiradores. Actitud que, por otra parte, cuenta con ilustres antecesores. Baste recordar el refugio de F. Petrarca (1304-1374) en Vaucluse cerca de Aviñón. Allá pergeñaría su obra De vita solitaria, donde recomienda a los aspirantes a poetas y filósofos «que recojan su espíritu en un lugar angosto, silencioso y recóndito». Tal vez porque la cabaña simboliza la «soledad centrada» ${ }^{20}$, en acertada expresión de G. Bachelard, constituye el lugar idóneo para llevar una existencia filosófica. Así lo entendieron dos de los pensadores más relevantes del siglo XX, quienes, por así decirlo, fueron víctimas del sindrome de Thoreau y sintieron el impulso de convertirse en ermitaños: M. Heidegger (1889-1976) y L. Wittgenstein (1889-1951).

El primero se hizo construir una cabaña de obra, revestida de madera, de apenas $6 \times 7$ metros de planta y tres habitaciones, con calefacción, aseo y agua corriente, en una abrupta pendiente en el límite del bosque, con vistas a los Vosgos y a los Alpes suizos, en un población situada al sur de Alemania, cerca de Friburgo de Brisgovia, en la Selva Negra. A partir del verano de 1922 y, por espacio de cinco décadas, hasta el final de sus días, se retiró por temporadas allí para trabajar en sus obras y preparar sus conferencias. Ese refugio en las montañas, al que se refería como «die Hütte» («la cabaña»), representó para él mucho más que un simple espacio para concentrarse en su trabajo. Se trataba,

19 Así describe C. Baker ese habitáculo en su retrato de grupo Emerson entre los excéntricos: «Henry se dedicó a construir una cabaña en la propiedad recién adquirida por Emerson en la orilla septentrional de Walden. Un bosquecillo de pinos blancos cayó bajo el hacha prestada de Henry; un trabajador del ferrocarril llamado James Collins le vendió una chabola abandonada, de la que él aprovechó los tablones y las tejas de madera gastada; la estructura de la casa se erigió en mayo y su dueño se instaló el día de la Independencia. Ya había despejado una hectárea de brezal contiguo para un huerto, sembrado cinco tipos de hortaliza -que sobrevivieron a las depredaciones de un pequeño ejército de marmotas-, construido un cobertizo y un excusado, y amueblado el interior con una cama, una mesilla, sillas, un pequeño escritorio y una lámpara y diversos utensilios de cocina. Colgado de una pared, había un espejo más pequeño que una postal de un penique. No podía ser todo vanidad en este ascético ménage de garçon». BAKER, C. (2008). Emerson entre los excéntricos, 26 Thoreau en Walden, trad. de I. Ferrer y C. Milla, Barcelona: Editorial Ariel, Biografías y Memorias, pp. 310-311.

${ }^{20}$ Bachelard, G. (1965). La poética del espacio, trad. de E. Champourcin, México: Fondo de Cultura Económica, p. 63. 
como escribe en Construir habitar meditar, de un lugar donde «volver a buscar la esencia del habitar ${ }^{21}$.

En 1913 L. Wittgenstein, por su parte, levantó con sus propias manos una rudimentaria cabaña de madera en Skoljen, en el extremo de la Lustrafford, en el corazón del distrito de los fiordos Sogn, a unos 250 kilómetros al noreste de Bergen, en un enclave rodeado de montańas y con vistas panorámicas al lago Eidsvatnet. El caso es que el joven, cosmopolita y mundano aprendiz de filósofo sintió la necesidad de alejarse de Cambridge, donde había pasado los dos últimos años siguiendo las lecciones de B. Rusell, y refugiarse en aquel recóndito paraje, en medio de ninguna parte, para serenar su ánimo inquieto, esquivar la depresión, restañar su maltrecho corazón y aclarar sus ideas. Según es creencia compartida por muchos historiadores de la filosofía, entre las desnudas paredes de aquella celda, no se sabe si de monje o de reo, germinarían las ideas del Tractatus. Otros ilustres ejemplos de cabañas de artistas son las de los músicos Gustav Mahler y Edvarg Grieg, el dramaturgo August Strindberg, los escritores George Bernard Shaw y Virginia Wolf, el poeta Dylan Thomas y una larga nómina de personajes que sería muy prolijo referir aquí.

Sólo resta decir que no todas las cabañas sirven de «espacios para pensar», por usar la expresión acuñada por el arquitecto inglés A. Sharr para referirse al refugio de M. Heidegger, sino que también pueden ser espacios destinados al ocio. El paradigma de ese modelo lúdico de cabaña es la casita de vacaciones, de apenas dieciséis metros cuadrados y montada con piezas prefabricadas, que Le Corbusier proyectó en una escarpada ladera en Roquebrune, Cap-Martin, sobre la bahía de Mónaco. Según refiere el propio arquitecto, esbozó el croquis de ese cabanon en menos de una hora en un papel volandero sobre la mesa de un chiringuito de la Costa Azul, L'Étoile de Mer, propiedad de su amigo T. Rebutato, como regalo para su mujer con motivo de su cumpleaños.

$\mathrm{Y}$, volviendo al tema de la cabaña de H. D. Thoreau, durante los veintiséis meses (dos años, dos meses y dos días) que duró su retiro, dio forma al borrador de su primer libro, inspirado en el viaje de dos semanas que realizó el 31 de agosto de 1839 junto a su hermano John por los ríos Concord y Merrimack, que no

${ }^{21}$ Heidegger, M. (2007). «Construir habitar meditar» en Filosofía, ciencia y técnica, prólogo de J. Acevedo y F. Soler, Santiago de Chile: Editorial universitaria. Véase también el catálogo de la exposición Cabañas para pensar, un proyecto de E. Outeiro Ferreño (2011) comisariado por A. Olmedo y J. A. Ruíz de Samaniego, Madrid: Fundación Luis Seoane Ediciones, Colección Larva. 
verá la luz en su versión definitiva hasta 1839 , tomó notas para una conferencia sobre el escritor escocés Thomas Carlyle (1795-1881), que sería el germen de un ensayo posterior y, sobre todo, redactó la primera de las siete versiones de Walden. Dejando aparte sus indiscutibles méritos literarios, ésta es una obra seminal y única también por su contenido, es decir, por los pensamientos que contiene. Además de una Escritura, Walden es un compendio de sabiduría práctica, una declaración de principios vitales y un vivero de ideas filosóficas. Viene muy a cuento la observación de S. Cavell cuando señala:

Thoreau caracteriza en el primer capítulo la filosofía como una «economía de la vida», una descripción que, en efecto, hace que el conjunto de Walden sea declarado una obra de filosofía (pues en conjunto trata de lo que Thoreau considera "economía»), de modo que establece que su autor es un filósofo y, en consecuencia, ofrece sus atributos imprevistos como rasgos por los que un filósofo puede ser reconocido (su morada, su vestido, su obra, sus posesiones, sus compañías, sus lecturas, sus formas de contar, de caminar, de transponerse en las cosas, cosas móviles e inmóviles) ${ }^{22}$.

Todavía hoy nos sorprende que H. D. Thoreau llevase hasta sus últimas consecuencias la fidelidad a sí mismo y la voluntad de forjarse su propio destino. Y nos admira que fuese al bosque para tomar lecciones de suficiencia y perfeccionar el arte de vivir libre de ataduras. En tal sentido resulta reveladora la observación de A. Lastra y J. Alcoriza: «Thoreau dejó Walden para que pudiéramos leer Wal$d e n$ : ése es el camino hacia el futuro» ${ }^{23}$. Su coherencia cívica y su coraje político le hacen parecer un radical cuando, únicamente, se negó a comprometer su independencia y se empeñó en bailar al ritmo de su propia música. Aunque es muy difícil identificarse con alguien tan íntegro, sacrificado consigo mismo y presto a mandarlo todo a paseo como él, cuesta mucho no sentir simpatía por su persona y sus ideas. La explicación a esta aparente contradicción quizá se encuentre en nosotros mismos. Quién más quién menos reconoce en él la parte insobornable, irreductible e insumisa de su propio ser, ese otro yo inmunorresistente a las imposiciones y los servilismos que todos tenemos, ese lado subversivo e insurgente, esa otra mitad sana, decididamente sana de nuestra persona. La honradez consigo mismo, la franqueza con que escribe y la firmeza de sus convicciones, rayana en

22 Cavell, S. (2011). "Thoreau piensa en lagunas, Heidegger en ríos», La Torre del Virrey, Revista de Estudios Culturales, 12, (2012/1), pp. 5-15. Véase también Cavell, S. (2011). Los sentidos de Walden, trad. de A. Lastra, Valencia: Pre-textos.

${ }^{23}$ Lastra, A. y Alcoriza, J. (2005). «Introducción», Walden, Madrid: Cátedra, Letras Universales n. ${ }^{\circ} 375$, p. 46. 
la vehemencia, nos cautiva, si bien no podríamos jamás ser como él. Nos parece ver concentrada en esta anotación de su Diario, fechada el de 27 de marzo de 1848 , toda su avidez vital y su audacia intelectual:

Persigue, alcanza, rodea tu vida como un perro en torno a la silla de su amo. Haz lo que amas. Conoce tu propio hueso; róelo, entiérralo, desentiérralo, y vuelve a roerlo. No seas solo bueno, sé bueno para algo. Todas las fábulas tienen su moraleja, pero los inocentes disfrutan con la historia ${ }^{24}$.

En definitiva, es alguien que, alérgico al oportunismo político y al sectarismo de cualquier signo, reivindica el derecho y también el deber de pensar por sí mismo. Su ideario filosófico, que rehúye las etiquetas y escapa a cualquier definición simplista, puede resumirse en tres palabras: libertad de pensamiento y obra. Ésa es su divisa. Sus posicionamientos ideológicos (antiesclavismo, antiimperialismo, antimercantilismo, pacifismo, su defensa de las minorías indígenas, del derecho a la holganza creativa y, por supuesto, de la naturaleza salvaje) derivan de ese planteamiento vital. Para decirlo claramente, H. D. Thoreau fue un intelectual comprometido consigo mismo, lo que, si bien se piensa, es la única forma de compromiso digna de respeto.

\section{La invención del genio del lugar ${ }^{25}$ o cómo imitar a la naturaleza con la naturaleza: Frederick Law Olmsted}

Así como H. D. Thoreau siempre estuvo tentado de dar la espalda a la civilización y encaminar sus pasos hacia «el lugar de la verdad», Frederick Law Olmsted (1822-1903) trató de incorporar la naturaleza salvaje a la ciudad,

${ }^{24}$ Thoreau, H. D. (2008), Escribir (una antología), ed. de J. Alcoriza y trad. de A. Casado da Rocha, Valencia: Pre-textos Editorial, p. 78.

${ }^{25}$ En su famosa Epístola en verso al conde de Burlington (An Epistle to Lord Burlington, 1731), incluida en su libro Moral Essays (1731), el poeta inglés Alexander Pope (1688-1744) escribe: «In all, let Nature never be forgot./ Consult the Genius of the Place in all,/ That tells the Waters or to rise, or fall,/ Or helps thambitious Hill the Heav'ns to scale, [...] Now breaks, or now directs, th'intending Lines;/ Paints as you plant, and as you work, Designs». («En todo, no olvides a la Naturaleza./ Consulta al Genio del lugar/ que ordena que las aguas asciendan o caigan/ que ayuda a las ambiciosas colinas a escalar los cielos o escalona los valles en anfiteatros circulares $[\ldots]$ y que ora rompe, ora dirige las líneas maestras/ y que Pinta cuando tú plantas, y mientras trabajas, Diseña».) Consultar al genio del lugar se convirtió en uno de los mandamientos fundamentales de la nueva estética paisajista, que imperó en el arte del jardín desde principios del siglo XVIII, cuyo ideal, valga la paradoja, era crear la ilusión de un parque natural. 
trayendo un trozo del bosque al corazón de Manhatann. Su nombre quedaría asociado para siempre al de Central Park, que realizaría junto a su socio, el arquitecto inglés Calvert Vaux. En 1858 ganan el concurso organizado por la ciudad de Nueva York para seleccionar el mejor proyecto destinado a la realización de un parque público que descongestionara la aglomeración metropolitana. Esa idea había sido impulsada por el mentor de ambos, Andrew Jackson Downing (1815-1852), quien perecería en trágicas circunstancias cuando se incendió y se fue a pique el barco que lo llevaba a Newport. El destino quiso que recayera sobre sus discípulos la tarea de hacer realidad su sueño de crear en Nueva York un parque de recreo, genuinamente americano y a disposición de todo el mundo. Aquél sería el primero de una larga serie de proyectos, diseñados en colaboración con C. Vaux o solo, que harían escuela.

F. L. Olmsted, siguiendo las doctrinas pintorescas ${ }^{26}$ que preconizaban los valores estéticos de la variedad (variety), la multiplicidad (multiplicity) y lo intrincado (intricacy), incorporó escenas salvajes al Central Park que evocaban el paisaje primitivo de los primeros tiempos. Tanto es así que pocas de las personas con las que se encontró el fotógrafo Geoffrey James, mientras retrataba con su cámara los parques diseñados por F. L. Olmsted, pensaban que eran «realmente creados» y una gran mayoría de ellas asumía, por el contrario, que eran «únicamente una parcela de naturaleza cercada» ${ }^{27}$. Lo cierto es que los rascacielos que rodean el perímetro del Central Park son visibles por doquier, impidiendo en la práctica abstraerse de la presencia de la metrópoli. Su interacción con el entorno, de hecho, tiene poco que ver con los postulados del pintoresquismo paisajista. A diferencia de los parques ingleses, que se servían de estrategias como el $h a-h a^{28}$

26 El término pintoresco deriva del vocablo italiano pittoresco, que significa capaz o digno de ser pintado. William Gilpin (1724-1804) aplicó por primera vez este calificativo en su Essay on Prints (1768), donde es definido como «la clase de belleza que podría verse bien en un cuadro». Con anterioridad a esa fecha, esa palabra había sido utilizada para designar algo gráfico o pictórico.

27 El gran historiador y profesor norteamericano de Arquitectura del Paisaje John Dixon Hunt (2000) reseña este hecho en su obra Greater Perfections. The Practice of the Garden Theory, Chapter 3 The Idea of a Garden and the Three Natures, London: Thames \& Hudson, p. 58. Geoffrey James, junto a Robert Burley y Lee Friedlander llevaron a cabo un proyecto fotográfico titulado Viewing Olmsted (Montreal, 1997), que fue financiado por el Canadian Centre for Architecture.

${ }^{28}$ Esta ingeniosa técnica de cerramiento, cuya invención se atribuye al gran maestro del jardín paisajista inglés William Kent (1685-1748), si bien tienen antecedentes en al arte militar de las fortificaciones, consiste en un foso o trinchera que interrumpe el paso a los visitantes sin obstaculizar la vista, y que permite que la barrera entre el parque y el entorno desaparezca y el paisaje se integre en el jardín o, mejor dicho, que éste se diluya en aquél. El curioso nombre de ha-ha 
para desdibujar sus contornos y fundirse con el paisaje circundante con objeto de crear la ilusión de un escenario sin límites, la planta del Central Park es claramente rectangular y está enmarcada por edificaciones y delimitada por un muro bajo de piedra, en el que se abren una serie de entradas o gates que facilitan el acceso a las cuatro vías subterráneas y transversales de comunicación, los diversos caminos para recorrer a caballo, los senderos destinados a los paseantes y el gran circuito anular. Así pues, mientras que en los jardines privados se celebraba una imagen de la naturaleza idealizada, cuyo libre disfrute era monopolio de una minoría acaudalada, el parque de F. L. Olmsted se presentaba como una depurada expresión de la cultura democrática y un medio de enseñanza de virtudes éticas y políticas, destinado a promover la socialización de los ciudadanos, contribuir al bienestar colectivo y a atenuar la creciente deshumanización de la superpoblada metrópoli. F. L. Olmsted, quien compartía la fe en el poder transformador de la democracia típica del pensamiento trascendentalista, concebía los parques como vastos espacios de educación popular y una escuela de moralidad pública. Bien sea como oasis verdes en medio de la jungla de asfalto o como pulmones de la congestionada urbe, éstos eran por vocación y por definición lugares de encuentro e integración social.

Su principal mérito es haber sabido adaptar la estética paisajista a las nuevas necesidades de la sociedad industrial y democrática. Consciente de la necesidad de dotar a las cada vez más populosas y florecientes ciudades norteamericanas de una red de parques públicos que sirvieran de recreo y esparcimiento a las clases trabajadoras, impulsó la realización de sistemas coordinados de espacios verdes y avenidas en Nueva York (Central Park, Prospect Park, Washington Park), Boston (Emerald Necklace) y Chicago (Jackson Park, Washington Park y Midway Plaisan$c e$ ). Añádase a todo esto la ejecución de numerosos jardines para particulares e instituciones como el Capitolio (Washington), el proyecto de varios campus como el de la universidad de Stanford, la habilitación de las zonas de esparcimiento de diferentes hospitales psiquiátricos y casas de reposo y la construcción de un par de cementerios. Ese verde legado se extiende de costa a costa de Estados Unidos y por Canadá.

proviene de la expresión de sorpresa manifestada por los eventuales caminantes al tropezar con un límite infranqueable. 
Forjó su original estilo, al que G. Shapiro ha tenido el acierto de definir como "pintoresquismo pragmático» ("pragmatic picturesque») ${ }^{29}$, a partir de múltiples y diversas influencias, que incluyen la lectura de los teóricos del movimiento pintoresco (Uvedale Price y William Gilpin), su conocimiento directo de algunos de los parques ingleses, en especial el realizado por Sir Joseph Paxton (1801-1865) en el suburbio de Birkenhead (Liverpool), al que se refiere en elogiosos términos como «un jardín destinado al pueblo» en su libro Walks and Talks of an American Farmer in England (1852), y su rica y variada experiencia vital como horticultor, marinero, viajero, periodista y paisajista autodidacta.

Debemos asimismo reconocerle el mérito de haber sido el primero en aplicar el término "parque» para designar a los grandes espacios naturales, en cuya conservación se implicó personalmente. Desempeñó un papel decisivo en la protección del área de Niagara Falls y lideró el comité que negoció con el presidente Lincoln la preservación del paisaje de las montañas Rocosas, en concreto de Yosemite Valley, que poseía un alto valor medioambiental y simbólico como imagen de la naturaleza preexistente al hombre, y su reconocimiento como «propiedad inalienable del público, así como un lugar de ocio y descanso» (1864). El haber ideado el concepto de «parque nacional» como reserva natural del paisaje virgen, conservado para las generaciones futuras, le convierte en un pionero en la protección del patrimonio paisajístico y en un precursor de las políticas medioambientales actuales. En consonancia con sus firmes convicciones democráticas pretende que todos los ciudadanos puedan gozar de los bellos paisajes, que, según él, ejercen un efecto moral y salutífero y una acción vivificante y regeneradora sobra las personas. Estas ideas fueron expresadas por F. L. Olmsted con las siguientes palabras en su Informe preliminar sobre Yosemite:

No hay duda de que el sometimiento excesivo y persistente a intereses sórdidos obstaculiza y se opone al de las bellezas de la naturaleza y destruye el amor que nos inspiraran, amor que el Todopoderoso implantó en nosotros mezclándolo tan íntima y misteriosamente en nuestro instinto y en nuestros sentimientos morales. En cambio, no es verdad que sea necesario no trabajar, tener mucho dinero, mucha cultura y mucho descanso para ejercer nuestra facultad de contemplar la naturaleza y de sentir lo que es bello. Es la locura

29 Shapiro, G. (2010). «The Pragmatic Picturesque. The Philosophy of Central Park», Gardening Philosophy for Everyone, Cultivating Wisdom, ed. de D. O'Brian, Wiley-Blackwell, Malden (USA), Oxford (UK): A John Wiley and Sons Ltd., Publication, Series Editor: Fritz Allhoff, p. 154. 
de las leyes lo que ha permitido y favorecido el monopolio que ejercen las clases privilegiadas sobre los medios que la naturaleza da a los hombres para satisfacer, ejercer y educar sus sentidos con lo que es bello; es ella la que ha marchitado, embotado y debilitado estas facultades en la masa que forman los súbditos de los reyes. Y es contra la limitación de esta educación al uso único de los ricos contra lo que deben ser dirigidas las leyes prudentes de los gobernantes libres ${ }^{30}$.

El tono de la prosa de F. L. Olmsted es menos vivaz y entusiasta que el de H. D. Thoreau y su entonación, sin duda, menos poética, pero su actitud hacia la naturaleza viene a ser la misma. Dejando aparte su respeto por los vastos espacios vírgenes y su reivindicación de la belleza salvaje, existen otras afinidades entre ambos polifacéticos e inspirados personajes, y no es la menor de ellas su oposición a la práctica del esclavismo y su firme compromiso con la causa abolicionista. Por la misma época en que H. D. Thoreau publicaba La esclavitud en Massachusetts (1854) y la Apología del Capitán Brown (1859), F. L. Olmsted realizó varios viajes (1852-1857) por los estados del sur y Texas, financiados por el The New York Daily Times, periódico en el que publicó numerosas crónicas, en las que juzgaba la dominación del hombre por el hombre no sólo moralmente reprobable sino ineficiente desde el punto de vista económico.

Un compendio de estos despachos sureños fue publicado en Gran Bretaña en 1861 con el título The Cotton Kingdom, atrayendo las simpatías de los lectores ingleses hacia la causa de la Unión. Al igual que H. D. Thoreau, F. L. Olmsted fue un periodista combativo y un ferviente defensor de la naturaleza. Y en tanto que abolicionistas y conservacionistas, ambos tuvieron un destacado papel como reformadores sociales. Cada uno a su manera intentó cambiar la sociedad que les tocó vivir. Desde una posición recalcitrantemente individualista en el caso de H. D. Thoreau y desde una perspectiva sociocomunitaria e higienista en el F. L. Olmsted, abrazaron la causa de la democracia con una seriedad que sería difícil de exagerar. Subscribimos las palabras de J. Martin, quien en su reciente biografía sobre F. L. F. Olmsted escribe:

At the same time, there's a common theme that runs trough many of Olmsted's diverse endeavors. First, last, always, he was a reformer. No disrespect to Americans who came of age in the 1940s, often called the «Greatest

30 Baridon, M. (2008). Los Jardines, siglos XIX y XX, Paisajistas Jardineros Poetas, Jardines de la era industrial, trad. de J. Calatrava y J. L. López, Madrid: Abada Editores, p. 345. 
Generation», but Olmsted cohort (those who came of age in the 1840s) was pretty great in its own right. It was an especially socially conscious period in the country's history, and it produced people who fought for the right of the physically disabled and the mentally ill and -in the North- for the freedom slaves ${ }^{31}$.

\section{De la arquitectura orgánica a la utopía libertaria: Frank Lloyd Wright}

Pasemos ahora a hablar de Frank Lloyd Wright (1867-1959), quien es un distinguido heredero de la vigorosa cultura trascendentalista del siglo XIX. Ese movimiento filosófico, literario y político que floreció aproximadamente entre 1836 y 1860 y que, pese a su nebulosa y heterogénea ideología, o tal vez por eso mismo, aglutinó a lo más granado de los intelectuales de su época: R. W. Emerson, H. D. Thoreau, W. Whitman, H. Melville, etc. Esa suerte de idealismo genuinamente norteamericano, de mística racional si eso es posible, bebe de fuentes muy dispares y en ocasiones contradictorias: el deísmo ilustrado, la filosofía romántica alemana, ciertos aspectos del pensamiento puritano y del igualitarismo y el humanismo propios de la Revolución Francesa. Los trascendentalistas adoptaron una actitud individualista y crítica con la sociedad de su tiempo, que era la de los albores de la industrialización. Y conjugaron ese acérrimo anticonformismo con un acusado espiritualismo, una acendrada fe democrática y un respeto casi sagrado por la naturaleza. No es casual que la biblia del movimiento sea Nature de R. W. Emerson ${ }^{32}$, quien constituye uno de los indiscutibles maes-

31 Martin, J. (20119. Genius of the Place. The Life of Frederick Law Olmsted, Abolitionist, Conservationist and Designer of Central Park, MA, USA: A Merloyd Park Book, Da Capo Press, A Member of Perseus Books Group, Cambridge, pp. 2-3. «Al mismo tiempo, una preocupación común late tras los diversos esfuerzos de Olmsted. Por encima de todo, fue un reformador. Sin restar méritos a los americanos que alcanzaron la mayoría de edad en los ańos cuarenta del pasado siglo, a menudo conocidos como la "Gran Generación», la cohorte de Olmsted (aquellos que llegaron a la mayoría de edad en la década de los cuarenta del siglo XIX) merece también esa consideración por derecho propio. Fue éste un período de la historia del país con una conciencia social especialmente aguzada, en el que surgió gente que luchó por los derechos de los discapacitados físicos, los enfermos mentales y -en el Norte- por la libertad de los esclavos», trad. del autor.

32 Desde muy temprano estuvo familiarizado con los escritos y las doctrinas de los trascendentalistas de Concord, por los que su madre sentía especial devoción. Las obras de Emerson, Thoreau, Channing, Parker, Whitman fueron algunas de sus primeras lecturas, a las que, paulatinamente, fue agregando los románticos Shelley, Byron y Blake. Así se entiende que en el último libro que publicó en vida, The Living City (La ciudad viva, 1958), incorpore un apéndice con un amplio fragmento resaltado en tinta roja del ensayo Agricultura de R. W. Emerson, 
tros de F. Lloyd Wright y una de sus influencias más perdurables. Si tuviéramos que escoger una frase que resumiera su contenido, sería «el hombre debe ser su propia Iglesia». Cada una de las palabras de esa oración cuenta. El ser humano puede por medio de la intuición y la contemplación directa de la naturaleza elevarse a un conocimiento superior, entrar en contacto con la fuente creadora de la vida y la energía cósmica. O para decirlo de otra manera, Dios se revela a sus criaturas sin intermediarios, a través de la Naturaleza. No parece exagerado afirmar que, en su etapa de madurez, la arquitectura de F. Lloyd Wright daba forma a los principios rectores del trascendentalismo y expresaba en un lenguaje espacial sus ideales. Identificaba éstos con los valores de la civilización oriental, con la que estuvo en contacto durante su estancia en Japón (1915-1921). De hecho, el trabajo de F. Lloyd Wright combina tres experiencias vitales (americana, europea y asiática) y aúna tres ideales: el retorno a la naturaleza salvaje de la tradición antiurbana norteamericana, los principios de sencillez, asimetría, impermanencia, aspereza rústica y simplicidad compositiva de la cultura budista y taoísta, y la búsqueda del equilibrio, la proporción y la armonía entre las partes del clasicismo occidental.

En su Autobiografía confiesa que, por lo demás, la experiencia más formativa de toda su vida fue el tiempo que pasó desde los 11 a los 17 ańos trabajando durante los meses de primavera y verano en la granja de su tío James en Wisconsin para ayudar a mantener la economía familiar, lastrada por el abandono de su padre. Esos orígenes rurales estuvieron muy presentes en su trabajo. Su sentido estético deriva de la temprana observación de la naturaleza y la apreciación de sus diseños y procesos. Gracias al aprendizaje vivencial de cómo la función crea la forma, empezó a admirar la simplicidad orgánica e hizo suya la idea romántica de que, en palabras de John Keats ${ }^{33}$, verdad y belleza son una y la misma cosa.

donde figura la célebre frase, que, por sí sola, resume su punto de vista sobre el tema: «Las ciudades violentan el crecimiento y hacen a los hombres parlanchines y divertidos, pero también los vuelven artificiales».

${ }^{33}$ Los últimos versos del famoso poema de J. Keat Ode on a Grecian Urn, rezan: «When old age shall this generation waste,/ Thou shalt remain, in midst of other woe/ Than ours, a friend to man, to whom thou say'st, / 'Beauty is truth, truth beauty, -that is all/ Ye know on earth, and all ye need to know'». ("Cuando el Viejo tiempo consuma esta generación/ tú continuarás, sumida en otro dolor/ que el nuestro, como amiga del hombre, a quien dices/ 'la belleza es verdad, verdadera belleza... esto es lo único que sabes en la tierra y todo lo que necesitas saber'».) KeATs, J. (1976). Poesía Completa, edición bilingüe, trad. de A. Sánchez, Barcelona: Libros Río Nuevo n. ${ }^{\circ}$ 12, pp. 126-129. 
Su arquitectura, a la que él mismo califica de orgánica, —una expresión que conceptualiza con insuperable claridad y precisión sus objetivos y su significado profundo-, promueve una relación armónica de las construcciones con el entorno. No se conforma con integrar los edificios en el paisaje, sino que pretende que éstos parezcan emanar de la naturaleza misma. Y para lograr esa naturalidad, hay que conjugar de manera sabia los materiales, el emplazamiento y el diseño. $\mathrm{Al}$ igual que los complejos sistemas bióticos, la casa y los alrededores deben estar interrelacionados, formando un todo continuo y un conjunto dinámico y fluido ${ }^{34}$. Estas ideas fueron expresadas por F. Lloyd Wright con estas poéticas palabras: «Los edificios como los árboles son hermanos para el ser humano. Edificios, árboles y hombres surgen todos de la tierra y crecen en busca de la luz».

La recomendación que acostumbraba a dar a sus alumnos no chirriaría en las páginas de cualquier ensayo de $\mathrm{H}$. D. Thoreau: «estudiar la naturaleza, amar la naturaleza, estar cerca de la naturaleza». Como el autor de Walden, sintió la llamada del horizonte y se dejó seducir por los grandes espacios abiertos y la tosca belleza de los paisajes salvajes. Un eco de ese antiurbanismo primigenio y constitutivo, casi biológico, del ermitaño de Concord se oye en las obras de F. Lloyd Wright. Como señala acertadamente D. Treiber: «Todos los escritos de Wright desacreditan a la ciudad, centro social artificial, decadente, de compromiso; ésta se opone al campo, espacio de regreso a las raíces, es decir, a la razón» ${ }^{35}$.

Salvando las distancias y los géneros creativos y dejando aparte otras consideraciones, ambos personajes adolecen de los mismos defectos y comparten parecidas virtudes: un individualismo irreductible, no exento de vanidad, una vitalidad contagiosa rayana en el fanatismo y un espíritu libertario que se disfraza de fe democrática. No obstante, F. Lloyd Wright tuvo una existencia más del doble de larga que la de su antecesor, en la que tuvo tiempo de reinventarse varias veces tanto profesional como sentimentalmente, renaciendo de las cenizas

${ }^{34}$ En su acreditada historia del jardín en la arquitectura del siglo XX, Darío Álvarez escribió: «La naturaleza, el paisaje y sus elementos, fueron vistos por el arquitecto en su estado más puro; sin embargo, su naturalismo no se limitó a una visión idílica de lo rural, sino que le llevó a indagar en la interpretación del paisaje como fuente de inspiración arquitectónica [...] Wright procuró buscar en todos sus proyectos un equilibrio entre el mundo natural y las abstracciones plásticas propias de la arquitectura. En este continuo diálogo, el jardín se convirtió en protagonista, y Wright se sirvió de él para extender la arquitectura de la casa hacia el paisaje y fundir ambos organismos en un sistema espacial único». Álvarez, D. (2007). El jardin en la arquitectura del siglo XX. Naturaleza artificial en la cultura moderna, capitulo 12 El jardin en la pradera, Barcelona: Editorial Reverté, p. 181.

35 Treiber, D. (1996). Frank Lloyd Wright, trad. de Y. Borja de Quiroga, Madrid: Akal, p. 88. 
y reengendrándose con renovado vigor ${ }^{36}$. Aunque vivió varias vidas, en ninguna de ellas sintió, parafraseando el viejo adagio medieval, que el aire de la ciudad le hacía libre. El siguiente fragmento extraído de uno de sus celebrados ensayos, Modern Architecture (1931), puede proporcionarnos una idea bastante precisa de hasta dónde podía llegar su rechazo a las urbes:

¿Acaso la ciudad no estuvo en otro siglo dirigida, aunque nos resulte difícil creerlo, a acrecentar la felicidad, las seguridad y la belleza de la vida del individuo considerado como ser humano? Ambos supuestos, sin embargo, son negados por el gran valor -un valor falso y antiamericano- que los partidarios del rascacielos han conferido a la congestión ${ }^{37}$.

He aquí otra muestra de las invectivas contra la ciudad que abundan en sus obras:

Creo que la Ciudad, tal como la conocemos hoy, va a morir. Estamos presenciando la aceleración que precede a la disolución. Nuestra civilización moderna, puede que no sólo sobreviva a la ciudad, sino que llegue a beneficiarse de ella; probablemente la muerte de la ciudad será el mayor servicio que la máquina prestará al ser humano si, por medio de ella, el hombre vence ${ }^{38}$.

${ }^{36}$ En su dilatada carrera profesional F. Lloyd Wright tuvo altibajos y crisis, pero no cayó nunca en el academicismo. A lo largo de sus siete décadas de ejercicio de la arquitectura volcó su versátil y polifacética creatividad en todo tipo de edificios: residencias campestres como las Prairie Houses (Casas de la Pradera) realizadas durante la primera década del siglo XX, véase Martin House (1904) en Buffalo (New York), Coonley House (1908) en Riverside (Illinois) o Roobie House (1909) en Chicago, edificios de oficinas como el Larkin Administration Building de Buffalo (1904) o el Administration Building de la S. S. Johnson Wax Company (Wisconsin, 1939), iglesias como The Unity Church (1906) de Oak Park o la iglesia unitaria de Madison (1947-1952), museos como el famoso edificio del Guggenhein (1943-46) de Nueva York, hoteles como el Imperial de Tokio (1916-1922), bibliotecas como la Florida Southern Library, rascacielos como el Price Tower de Bartlesville (Oklahoma) en 1953, proyectos urbanísticos como el Florida Southern Collegue, restaurantes como el Midway Gardens (1913-14) al sur de Chicago o casas de autor como Kaufman House, más conocida como la Casa de la Cascada (1936-37) en los bosques de Pensylvania, tal vez su edificio más icónico, y por supuesto su estudio-escuelaresidencia de Taliesi I y II.

37 Wright, F. L. (2010). Modern Architecture, 5 La tiranía de los rascacielos, trad. de F. MelerOrtí, Barcelona: Paidós Estética, p 216.

38 Op. cit., 6 La ciudad, pp. 229-230. 
Con el mismo desdeñoso tono, acentuado por su estilo ampuloso y su decimonónico idealismo, describe la ciudad de Nueva York en una conferencia dictada en la universidad de Princeton en 1930:

[Nueva York], con montones de riqueza material que se apila cada vez más alto en el aire, es una máquina comercial falsamente condicionada por un tenue disfraz. El disfraz es una colección de fachadas de ladrillo y hormigón, letreros deslumbrantes y paredes muertas que se levantan a uno y otro lado de la garganta de un cañón. ¡En los estrechos senderos de abajo todo gruñe, retumba y grita! En realidad la gran máquina hecha de máquinas es un bosque de pilares de acero remachados, rieles remachados, modillones remachados y bloques de hormigón reforzados con acero, encerrados por pesadas paredes de piedra y ladrillo, todo ello sostenido por la misma estructura de acero, rematado finalmente por depósitos de agua, retranqueos y agujas, paredes muertas decoradas con anuncios exagerados o púdicamente pintadas con enladrillados de color $^{39}$.

Resulta curioso e ilustrativo comparar esta descripción, en el mejor de los casos poco amable, de Nueva York realizada por F. Lloyd Wright cuando era un arquitecto consagrado de 63 años en la cima de su gloria, con la impresión no menos hostil y desalmada que le produjo Chicago cuando en los lejanos días de 1880, con apenas 18 ańos cumplidos, llegó a la ciudad para trabajar como delineante en el despacho de Adler \& Sullivan:

Chicago... corrientes contrarias de caballos, de camiones, de tranvías chirriantes deslizándose por duros raíles, melés de seres humanos sumidos en una confusión y un clamor aparentes... Bruma, sombra, nubes de humo. Cegado por el humo, y fumando... El estruendo de este embotellamiento de fuerzas ciegas era horrible. Si lo que estaba viendo tenía alguna lógica, ¿quién podría entenderla? ${ }^{40}$.

Es evidente que, a lo largo de los años, no varió mucho su percepción de las grandes metrópolis, a las que culpaba de socavar los valores humanos e individuales. Esta convicción o, mejor sería decir, obsesión antiurbana le acompañó

39 Op. cit., 5 La tiranía de los rascacielos, pp. 222-223.

40 Wright, F. L. (1998). Autobiografía: 1867 (1944), presentación, traducción y notas de J. Avendaño, Madrid: El Croquis Editorial, Biblioteca de Arquitectura, p. 57. Véase también: Secrest, M. (1998). Frank Lloyd Wright: A Biography, Chicago: University of Chicago Press. 
hasta el final de sus días. A una edad en que otras personas se jubilan o crían malvas, el venerable F. Lloyd Wright expuso por escrito su modelo de ciudad ideal en un libro que metió mucho ruido, pero que, hoy en día, pocos leen, The Disappearing City (1932). El proyecto de Broadacre City: A New Community $P_{l a n}{ }^{41}$, acompañado de una maqueta, gráficos y dibujos, fue oficialmente presentado en 1935 en la Industrial Arts Exposition, que tuvo lugar en el Rockfeller Center de Nueva York. Emparentada con la ciudad jardin de Ebenezer Howard (1850-1928) y el City Beautiful Movement de F. L. Olmsted, esa utopía urbana se halla en el polo opuesto de Le Ville Radieuse (1935), la ciudad sońada por Le Corbusier (1887-1965), constituida por gigantescos rascacielos con terrazas ajardinadas levantados sobre pilotis en medio de un parque continuo, únicamente interrumpido por autopistas y carreteras. Broadacre City sigue, por el contrario, un modelo de ocupación del territorio de baja intensidad y una tipología unifamiliar aislada, basado en la retícula jeffersoniana (utilizada en la fundación de las primeras ciudades norteamericanas). La población se distribuye en viviendas independientes repartidas en parcelas de al menos cuatro acres de extensión ( 1 acre $=4.000$ metros cuadrados $)$ y conectadas por una amplia red de vías de comunicación lineal, que facilitan un acceso homogéneo y democrático a la casa.

A la hora de diseñar esa polis del futuro, que se suma a la ya larga tradición de urbes utópicas iniciada por la República de Platón y seguida por Citerea, Sforzinda, Palmanova y tantas otras, F. Lloyd Wright tuvo en cuenta dos principios rectores: la calidad ambiental y la circulación fluida. Sobra decir que éstos son dos de los aspectos más claramente amenazados en las grandes aglomeraciones urbanas de su época. Su fe en la democracia, típica por lo demás del pensamiento trascendentalista, inspira Broadacre City, de la que dice en su Autobiografía que es «tan agraria como urbana» y que se extiende en todas las direcciones. Esa ciudad descentralizada y difusa, cuyo centro se halla en todas partes y en ninguna, presenta, sin embargo, más de un inconveniente. No hace falta ser un experto en arquitectura para darse cuenta de que, en aras de humanizar las condiciones de vida de los ciudadanos y propiciar su retorno al campo, potencia el uso del automóvil, un consumo desmedido del territorio y el aislamiento social. La disponibilidad de tierras para todos y el derecho inalienable, casi sagrado, a poseer una parte del territorio son dos ideas, características del mito romántico de la

${ }^{41}$ La etimología de ese extraño neologismo ideado por F. Lloyd Wright evidencia sus propósitos: Broad (en inglés: ancho, abierto, claro) y acre. Las publicaciones en las que habla de Broadacre City son, aparte del libro ya mencionado, Architecture and Modern Life (1937) escrito en colaboración con B. Brownell, When Democracy Builds (1945) y The Living City (1958). 
frontera nacido al amparo de la conquista del Oeste, que subyacen, por no decir sustentan, ésta más que cuestionable utopía. Eso demuestra, si es que hubiera necesidad de tal prueba, que F. Lloyd Wright padecía lo que hemos dado en llamar el sindrome de Thoreau: una creencia irracional en que la ciudad priva a los hombres de su libertad y sus valores esenciales. O para decirlo más claramente, sólo es posible llevar una vida auténtica en contacto con la naturaleza.

Del prolífico legado de F. Lloyd Wright a la posteridad no son, desde luego, sus acerbas críticas a la ciudad lo que mejor resiste el paso del tiempo. Así como la arquitectura orgánica es un concepto visionario, seminal y duradero, que sigue ejerciendo una proteica influencia sobre las nuevas generaciones, su alternativa a la masificación deshumanizadora y a la mecanización de las grandes metrópolis, materializada en su Broadacre City, produce más pasmo que admiración. Ese modelo de desarrollo urbanístico a partir de una malla de poblamiento disperso da lugar a una ciudad sin personalidad, con calles carentes de entidad propia y desprovistas de un centro destinado a la socialización como en la ciudad tradicional, y cuya máxima expresión son los barrios suburbiales y las urbanizaciones residenciales de las periferias urbanas.

\section{Del arte de la tierra al paseo como una de las bellas artes}

Permítame el lector que, para acabar de ilustrar la pervivencia en la cultura anglosajona contemporánea de ese impulso antiurbano que hemos bautizado como el sindrome de Thoreau, nos ocupemos durante unas páginas del Land Art. Apenas nueve años después de la desaparición del más gran arquitecto norteamericano de todos los tiempos, tiene lugar el acto de fundación de ese movimiento, que estaba llamado a revolucionar el panorama artístico, por aquel entonces en plena ebullición, de la década de los años sesenta y setenta del siglo pasado. En 1968 la exposición colectiva Earthworks en la mítica galería de Virginia Dwan en Nueva York reunió a creadores como R. Smithson (1938-1973), W. De Maria (1935), M. Heizer (1944), R. Morris (1931) y D. Oppenheim (1938-2011). Algunos de estos prometedores jóvenes (R. Smithson, R. Morris y D. Oppenheim) y otros nuevos (C. André, Sol LeWitt, C. Oldenburg) participaron al año siguiente en la exposición que organizó la Cornell University bajo el lema Earth Art. Estas exposiciones darían nombre y visibilidad a un particular modo de creación artística, que combinaba la austeridad formal del Minimalismo, la densidad significativa y la reflexividad del Arte Conceptual y la dimensión mítica 
del Arte Povera, y marcarían el nacimiento de lo que, con el tiempo, acabaría conociéndose como Land Art ${ }^{42}$.

No deja de ser irónico que los orígenes de esta corriente estén vinculados a sendas exposiciones, cuando uno de los pocos rasgos en común de esa tan heterogénea como variopinta hornada de artistas era justamente el rechazo a la comercialización del arte y la voluntad de sacar las obras de sus marcos expositivos tradicionales. A esta antimercantilización se añadía el desafío a la ortodoxia académica, la crítica a las formas escultóricas tradicionales y la impugnación a la rígida teoría moderna. $\mathrm{Al}$ escoger los vastos, remotos y despoblados parajes desérticos de las tierras del Oeste (de Nevada y California), que también habían inspirado a F. Lloyd Wright, y utilizar en ellas elementos del terreno (rocas, tierra y agua), en ocasiones combinados con materiales industriales como hormigón, asfalto, acero,... pretendían modificar la definición de escultura y la manera en que los espectadores percibían las obras. Aspiraban a renovar el lenguaje formal del arte, a encontrar nuevos cauces para expresar su sentimiento antiurbano y a rebasar los límites, ir más allá y establecer nuevas fronteras para la creatividad. Earthworks, Earth Art, también conocido como Ecologial Art, Nature Works, Process Art, Environmental Art, Site-specific Projects y una multitud de nombres más, que no siempre corresponden a un trabajo escultórico sino a un site performance, intervenciones transitorias $\mathrm{o}$, incluso, meros procesos mentales, como veremos

42 Entre las realizaciones más emblemáticas de estos pioneros del Land Art, que abrieron nuevos caminos y crearon escuela, se encuentra Spiral Jetty (1970) de R. Smithson. Se trata de un malecón en forma espiral construido con rocas, barro y cristales de sal en la orilla del Great Salt Lake, cerca de Rozel Point, en Utah, y que, por temporadas, coincidiendo con la crecida de las aguas, queda parcialmente sumergido. Otro de los trabajos seminales de este movimiento artístico fue The Lighting Fields (1974-77) de W. De Maria, una instalación formada por cuatrocientos postes de acero terminados en punta, de unos cinco metros de altura, que se levantan hacia el cielo para atraer los rayos en una parcela de 1 X 1'6 kilómetros en el desierto de Nuevo México. Durante las frecuentes tormentas eléctricas el ensordecedor sonido de los truenos se suma a los destellos de los rayos y centellas provocando un insólito espectáculo. No menos significativa es la obra Double Negative (1969) de M. Heizer, consistente en dos enormes fosas de unos 450 metros de longitud por 15 metros de profundidad y 9 metros de ancho excavadas en el desierto de Nevada, que invitan a la reflexión sobre el papel de la escultura ausente. J. Turnell (1943), por su parte, se ha dedicado varios años a transformar Roden Crater, un cono volcánico situado en Flagstaff (Arizona), en un observatorio celeste. Y, por último, podemos acabar esta incompleta selección mencionando a Nancy Holt (1938), la artífice de Sun Tunnels (1973-76), una instalación consistente en cuatro grandes tubos huecos de hormigón de nueve pies de diámetro emplazados en el desierto de Utah. Esos enormes cilindros están dispuestos en forma de $\mathrm{X}$ abierta y alineados con la salida y la puesta del sol durante los solsticios de invierno y de verano. Cada uno de ellos se halla, por lo demás, perforado en varios puntos siguiendo el esquema de representación de diferentes constelaciones (Draco, Perseo, Capricornio, Columba). 
más adelante. Frente a los artefactos artísticos consagrados por la crítica y expuestos como fetiches entre las paredes de las galerías de moda, ellos preferían exhibir sus obras al aire libre, en non-sites, por usar la elocuente expresión acuñada por R. Smithson para definir sus efímeras realizaciones en medio del paisaje, donde estaban sometidas al deterioro progresivo y la acción erosiva de los elementos. De ahí también que documenten fotográfica y fílmicamente la ejecución de sus creaciones y su posterior degradación. Esos registros visuales, junto con mapas, dibujos y textos, constituyen por lo general el material expositivo. Vale la pena detenerse en este punto para subrayar que la noción de proceso está muy presente en sus obras, tanto el proceso creativo del artista como el perceptivo del espectador.

En su afán por establecer la genealogía de este arte de la tierra y entroncar sus realizaciones con la tradición estética, R. Smithson, uno de los portavoces e ideólogos del movimiento, reivindicaba la figura de F. L. Olmsted como el primer "land artista» ("America's greatest earthworks artist») $)^{43}$. A su entender los enormes movimientos de tierras y rocas necesarios para crear colinas, lagos, bosques y, en suma, un majestuoso paisaje pintoresco en la isla de Manhatann (Central Park) lo convertían en el precursor de esa corriente artística, lo que, bien mirado, parece una exageración interesada sin demasiado fundamento. De todos modos, la etiqueta Land Art engloba a una dispar y heteróclita nómina de creadores que difieren mucho en sus propósitos, técnicas y materiales. Tienen, eso sí, como mínimo común denominador: el haber trasladado el trabajo artístico a la naturaleza. Su rasgo distintivo es que realizan intervenciones en el territorio más o menos efímeras, en ocasiones reciclando elementos proporcionados por éste como materia prima, y que se sirven del paisaje como marco y soporte. A pesar de las enormes diferencias entre unos y otros en cuanto a técnicas e intenciones, podemos agruparlos, al menos, en dos categorías en función de si interactúan con la naturaleza de forma más o menos respetuosa. Seguimos en esto a Javier Maderuelo ${ }^{44}$, quien utiliza dos términos diferentes para etiquetar sus realizacio-

43 Smithson, R. (1996). "Frederick Law Olmsted and the Dialectical Landscape» (1973), The Complete writings, ed. de J. Flam, Berkeley/Los Ángeles/Londres: University of California Press. Existe una traducción en castellano de este ensayo de H. Smith publicada en el catálogo de la exposición sobre Robert Smithson (1993), Valencia: IVAM Centre Julio González, pp. 174181, y reproducida en Naturaleza y artificio, El ideal pintoresco en la arquitectura y el paisajismo contemporáneos, ed. de I. Ábalos, Barcelona: Editorial Gustavo Gili, Compendios de Arquitectura Contemporánea, pp. 31-48.

${ }^{44}$ Maderuelo, J. (2007). Paisaje y arte, Madrid: Abada Editores, Colección Pensar el paisaje 02 (CDAN 2009). 
nes. Así pues, opta por usar la palabra Earthworks para referirse a los artistas, en su mayoría norteamericanos, que intervienen en el territorio de forma contundente y agresiva, sin cuestionarse el impacto medioambiental de sus acciones, ni reparar en gastos, ni en la utilización de maquinaria pesada (excavadoras, buldózeres, camiones, etc.), llegando a modificar el paisaje de forma ostensible y permanente. Ni que decir tiene que H. D. Thoreau se revolvería en su tumba si pudiera ver algunas de las intervenciones, acciones, performances o llámenlas como quieran de estos artistas de la tierra. La arrogancia con que se apropian del marco natural e interfieren arbitrariamente en el paisaje, parasitando, cuando no vampirizando, su belleza, se halla en la antípoda de la veneración y el respeto por la naturaleza virgen del autor de Walden ${ }^{45}$. J. Maderuelo reserva el apelativo Land Art exclusivamente para aquellos artistas, por lo general europeos pero no siempre, para los que el territorio es el medio y el tema de acciones creativas. Sus intervenciones apenas alteran el paisaje o lo hacen de forma transitoria o imperceptible. De hecho, el respeto y el goce de la naturaleza, así como el retorno a la pureza de los orígenes son sus divisas.

A esta última categoría pertenecen dos de los land artistas más interesantes de los últimos años: Richard Long (1945) y Hamish Fulton (1946), a los que correspondería mejor la etiqueta de artistas peripatéticos, pues ambos han hecho del arte de caminar la materia prima y la seña de identidad de su trabajo. De hecho, han recorrido juntos la Península Ibérica de costa a costa en los años 1989 y 1990. Lejos de introducir cambios definitivos en el paisaje o apropiarse de las bellezas naturales, las acciones de estos dos artistas ingleses extreman el respeto por el entorno y procuran captar el aliento de la naturaleza, sin perturbar su equilibrio ni dejar apenas huella de su paso. En la página web oficial de R. Long figura la siguiente declaración de principios:

45 Compartimos la opinión de Francisco de Gracia, quien a este particular, observa con sombría lucidez: «Muchas de las earthworks no se idean para integrarse en el paisaje geográfico, contra lo que sus autores pudieran aducir, sino que en casos extremos llegan a vampirizar la sustancia de algunos territorios destacados: desiertos inmensamente vacíos, hermosas playas vírgenes, remotas formaciones volcánicas. Hablamos de artistas hechos al medio cultural urbano que escenifican un cierto rechazo a la ciudad para justificar sus instalaciones en parajes antropizados, sabedores de que su intervención provoca una imagen destacada gracias a un fondo majestuoso. Cierto que a veces se trata de montajes provisionales o de performances fugaces, donde interesa más el acontecimiento que la perpetuación del objeto. En tales casos, en efecto, el proceso o la acción importan más que el resultado, algo que estuvo especialmente presente en el ideario del situacionismo, una influyente vanguardia antisistema y antinaturalista de los años sesenta». Gracia, F. de (2009). Apuntes sobre la razón constructiva, 03 Varia Paisajistica, Entre la arquitectura y el paisaje, Nerea, Donostia-San Sebastián: Nerea, p. 64. 
In the nature of things: art about mobility, lightness and freedom. Simple creative sets of walking and marking about place, locality, time, distance and measurement. Work using raw materials and my human scale in the reality of landscapes.

The music of stones, paths of shared footmarks, sleeping by the river's roar $^{46}$.

Uno de sus primeros trabajos lleva por título $A$ line made by walking (1967) y consiste simple y llanamente en una línea trazada en la hierba a fuerza de ir y venir sobre sus pasos. Desde entonces, ha llevado a cabo numerosas obras de arte caminando en paisajes y países diversos. Esa forma de «hacer esculturas andando", por utilizar una expresión de su agrado, recuerda los paseos solitarios de H. D. Thoreau por los bosques de Concord (Massachussets). En su inolvidable ensayo Walking (1862) escribe:

La mitad de la caminata consiste en volver sobre nuestros pasos. Tal vez debemos lanzarnos al más corto de los paseos con espíritu de imperecedera aventura, con la idea de no regresar jamás, listos para enviar sólo el corazón embalsamado a nuestro desolado reino. Si estás preparado para dejar a tu padre y a tu madre, hermano y hermana, mujer, hijos y amigos, y no volver a verlos... Si has pagado tus deudas, hecho tu testamento y dejado tus cosas en orden... Si eres un hombre libre, entonces estás listo para echar a andar ${ }^{47}$.

H. Fulton, por su parte, se define a sí mismo como «un artista que anda» y que realiza «arte desde la experiencia de sus caminatas». No está de más mencionar que ha recorrido veinte cuatro países a pie, documentando prolijamente con fotografías, a menudo en blanco y negro, y breves textos sus solitarias marchas por paisajes vírgenes (montañas, acantilados, bosques, volcanes, etc.), en las que, a diferencia de su colega $\mathrm{R}$. Long, no interviene en el lugar representado ni deja efímeras marcas como círculos o alineamientos de piedras. Se complace en llamar a sus acciones «esculturas mentales» («mental sculptures»), quizá para subrayar su

46 «En la naturaleza de las cosas: arte sobre movilidad, ligereza y libertad. Simples juegos creativos de caminar y señalizar sobre lugar, localidad, tiempo, distancia y medida. Trabajar con materias primas y mi escala humana en la realidad de los paisajes.

La música de piedras, caminos de huellas compartidas, durmiendo por el rugido del río», trad. del autor.

47 Thoreau, H. D. (1999). Pasear, trad. de S. Komet, Palma de Mallorca: José J. de Olañeta Editor, p. 7. 
filiación artística, dado que implican nociones de espacio, tiempo y materia. Toda su filosofía creativa se halla capturada en este párrafo memorable:

¿Por qué caminar? Caminar es la respuesta. Para mí caminar no es una teoría, caminar no es un material artístico; la caminata es una experiencia, es una forma artística de pleno derecho. Tras varios días caminando, tengo la impresión de que puedo pensar con mayor claridad, surgen preguntas y lucho mentalmente por contestarlas ${ }^{48}$.

El trabajo de este fotógrafo caminante está claramente emparentado no sólo con la tradición británica de la pintura de paisaje, como él mismo sugiere, sino también con la literatura de H. D. Thoreau, quien asimismo hizo de sus experiencias vitales la materia prima de sus obras y registró los resultados de ese experimento consigo mismo en las páginas de su Diario y sus libros. Tanto R. Long como H. Fulton encarnan a la perfección el espíritu montaraz, la vocación nómada y el irredento individualismo de ese filósofo de la naturaleza que fue $\mathrm{H}$. D. Thoreau. Como él, se han convertido en profesionales de la falta de oficio. Manifiestan su misma sensibilidad por la naturaleza salvaje y su afición a perderse por los caminos a la búsqueda de sí mismos y a no instalarse en la vida ni dejarse atrapar por el trabajo. Al igual que para el carismático Thoreau, caminar es su forma de estar en el mundo, de no rendirse a una existencia de tranquila desesperación y de preservar su libertad.

Herederos del romanticismo, que convirtió el arte del paseo en una actividad cultural ligada a la contemplación y al disfrute de la naturaleza, R. Long, H. Fulton y otros artistas con el don de la deambulación creativa, intentan subvertir los signos y auspiciar nuevos significados, provocando un acontecimiento significativo y pasajero a la vez en el curso del viaje a pie por la vida. No creo exagerado afirmar que, si hoy volviera a nacer, $\mathrm{H}$. D. Thoreau bien podría engrosar las filas de estos artistas de la legua, hermandad a la que también pertenecieron otros ilustres pensadores como F. Nietzsche o J. J. Rousseau, y cuya filosofía fue inmejorablemente expresada por el autor de Las Confesiones con estas palabras: «No puedo meditar sino andando, tan pronto como me detengo, no medito más, mi cabeza anda al compás de mis pies».

${ }^{48}$ Fulton, H. (2005). Siete caminatas, Lanzarote: Fundación César Manrique, p. 12. 


\section{Bibliografía}

Amara, L.: La escuela del aburrimiento, Un experimento de autarquía, Editorial Sexto Piso, México, 2012.

Arenas, L.: Fantasmas de la vida moderna, Ampliaciones y quiebras de sujeto en la ciudad contemporánea, Editorial Trotta, Serie Filosofía, Madrid, 2011.

Bachelard, G.: La poétique de l'espace, Presses Universitaires de France, Paris, 1957.

Dixon, J.: The Figure in the Landscape, Poetry, Painting, and Gardening during the Eighteenth Century, The Johns Hopkins University Press, Baltimore and London, 1976.

- Gardens and the Picturesque. Studies in the History of Landscape Architecture, The MIT Press, Cambridge, Massachusetts, London, England, 1994.

Dixon, J. y Willis, P. (edited by): The Genius of the Place. The English Landscape Garden 1620-1820, The MIT Press, Cambridge, Massachusetts, London, England, 1988.

FARIELlo, F.: La arquitectura de los jardines. De la antigüedad al siglo XX, traducción y edición de J. Sainz, Editorial Reverté, Barcelona, 2004.

Gifford, T.: Pastoral, The New Critical Idiom Series Editor: J. Drakakis, University of Stirling, Routledge, Taylor \& Francis Group, London and New York, 1999.

Harding, W.: The Days of Henry David Thoreau, Princeton University Press, 1992.

Heidegger, M.: Construir habitar pensar, Editorial Serbal, Barcelona, 1994.

Lastra, A. (ed.): Desobediencia civil. Historia y antología de un concepto, Tecnos, Los esenciales de la Filosofía, Madrid, 2012.

- Emerson como educador, editorial Verbum, Madrid, 2007.

- Emerson transcendens / La trascendencia de Emerson, Biblioteca Javier Coy d'estudis Nord-Americans n. ${ }^{2}$ 29, Publicacions Universitat de València (PUV), 2004.

López AnAya, J.: El extravio de los limites, Claves para el arte contemporáneo, Emecé Arte, Buenos Aires, Argentina, 2007.

Rodríguez Llera, R.: Paisajes arquitectónicos, Universidad de Valladolid, Serie Arquitectura y Urbanismo n. ${ }^{\circ}$ 69, 2009.ROSS, S.: What gardens mean, The University of Chicago Press, Chicago and London, 1998.

Saint Girons, B.: Lo sublime, traducción de J. A. Méndez, La balsa de la medusa n.o 162, Serie Léxico de estética, colección dirigida por Remo Bodei, Madrid, 2008.

Sharr, A.: La cabaña de Heidegger. Un espacio para pensar, Editorial Gustavo Gili, Barcelona, 2009. 
Thoreau, H. D.: The writings of Henry David Thoreau, Houghton Mifflin, New York, 1906.

Vergara, A. y De Las Rivas, J. L: Territorios Nuevos, Nuevos horizontes del urbanismo, Fundación Metrópoli, Madrid, 2004.

VV.AA.: Cabañas para pensar, catálogo de la exposición homónima, un proyecto de E. Outeiro Ferreño, comisariado por A. Olmedo y A. Ruiz de Samaniego, Fundación Luis Seoane, Ayuntamiento de A Coruña, Concello da Coruńa, MAIA ediciones, Madrid, 2011.

Recibido: 24/04/2013

Aceptado: 24/07/2013 